\title{
DESINFECÇÃOQUÍMICA APLICADA NA AVICULTURA: CONCENTRAÇÕES INIBIDORAS MÍNIMAS DE DESINFETANTES DERIVADO DA AMÔNIA QUATERNÁRIA E HIPOCLORITO DE SÓDIO SOBRE Salmonella sp E Escherichia coli*
}

CLAUDIO ROBERTO CROS LEITE

José Maria Wiest (Orientador - UFRGS)

Banca Examinadora:

Guiomar Pedro Bergmann UFRGS

Isa Beatriz Noll UFRGS

Maristela Lovato Flôres UFSM

Este trabalho foi desenvolvido com o objetivo de avaliar a eficácia de produtos desinfetantes derivados da Amônia Quaternária e Hipoclorito de sódio, utilizados na avicultura, frente às espécies bacterianas Salmonella Enteritidis, Typhimurium, Hadar, Heidelberg isoladas de carcaça de frango e de três Escherichia coli isoladas de frangos de corte com problemas respiratórios. Os desinfetantes testados, ambos de USO GERAL, foram avaliados através da Técnica de Diluição Serial com Sistemas de Tubos Múltiplos conforme preconizado pela Sociedade Alemã de Medicina Veterinária e Sociedade Alemã de Higiene e Microbiologia. Os resultados obtidos neste trabalho mostram que a Concentração Inibidora Mínima (CIM) da Amônia Quaternária foi de 0,64842\%, enquanto que para o Hipoclorito de sódio foi de 1,58333\%. Estes dados demonstram que, independente da amostra bacteriana, a Amônia Quaternária apresentou um melhor desempenho do que o Hipoclorito de Sódio.As salmonelas apresentaram a maior resistência frente a ambos os desinfetantes testados. Entre as bactérias utilizadas neste teste, a Salmonella Enteritidis apresentou a maior resistência. Na avaliação individual por desinfetante, a Salmonella Enteritidis e a Salmonella Heidelberg, demonstraram a maior resistência frente a amônia, enquanto que a Salmonella Hadar foi a mais resistente frente ao Hipoclorito de Sódio. As diluições de uso da Amônia Quaternária, recomendadas pelo fabricante, foram todas ineficazes frente às bactérias usadas neste teste; não haviam recomendações de uso no Hipoclorito de Sódio. Estes resultados sugerem a necessidade de tornar rotina a avaliação dos desinfetantes usados em saúde e produção animal.

Descritores: desinfecção, avicultura, amônia quaternária, hipoclorito de sódio, sanidade.

Apresentada: 24 setembro 2001

* Dissertação de Mestrado n.’316 (Especialidade: Medicina Veterinária Preventiva). 105f. Programa de Pós-Graduação em Ciências Veterinárias da Faculdade de Veterinária, Porto Alegre - UFRGS.CORRESPONDÊNCIA: J.M.Wiest [e-mail: jmwiest@vortex.ufrgs.br] 


\title{
CHEMICAL DISINFECTION APLLIED IN POULTRY INDUSTRY: MINIMAL INIBITORY CONCENTRATION OF DISINFECTANTS DERIVATE FROM QUATERNARY AMMONIUM AND SODIUM HIPOCHLORITE IN Salmonella sp AND Escherichia coli**
}

\author{
CLAUDIO ROBERTO CROS LEITE
}

José Maria Wiest (Adviser - UFRGS)

\author{
Committee: \\ Guiomar Pedro Bergmann UFRGS \\ Isa Beatriz Noll UFRGS \\ Maristela Lovato Flôres UFSM
}

This work was developed with the objective of evaluating the efficacy of disinfectants products, derivate from the Quaternary Ammonium and Sodium Hipochlorite used in poultry industry, in relation to bacterial species Salmonella Enteritidis, Typhimurium, Hadar, Heidelberg isolated from chicken carcase and Escherichia coli isolated from slaughter chicken with breathing problems. The disinfectants tested, both of GENERAL USE, were evaluated through the Serial Dilution Technique with Systems of Multiples tube according to what is advocated by the Germani Society of Veterinary Medicine and Germani Society of Hygiene and Microbiology. The results obtained in this work show that the Minimum Inhibit Concentration (CIM) of Quaternary Ammonium was $0,64842 \%$, whereas the Sodium Hipochlorite was $1,58333 \%$. These data show that independently of bacteria sample, the Quaternary Ammonium showed a better performance than the Sodium Hipochlorite. Salmonela showed higher resistance in relation to both disinfectants tested. Amoung the bacteria used in this test, the Salmonella Enteritidis showed higher resistance. In the individual evaluation by disinfectant, the Salmonella Enteritidis and the Salmonella Heidelberg showed higher resistance in relation to Ammonium, whereas the Salmonella Hadar was the most resistant in relation to the sodium Hypochlorite. The dilutions of the use of Quaternary Ammonium, recommended by the manufacturer, where all inefficient in relation to the bacteria used in this test there were no recommendations of becoming routine the evaluation of disinfectants used in health and animal production.

Key words: disinfection, poultry industry, quaternary ammonium, sodium hipochlorite, animal health. 